\title{
BROKEN SPELEOTHEMS AS INDICATORS OF TECTONIC MOVEMENTS
}

PRETRTA SIGA KOT POKAZATELJ TEKTONSKIH PREMIKOV

\author{
Stanka ŠEBELA ${ }^{1}$
}

\begin{abstract}
UDC 552.545:551.248

Stanka Šebela: Broken speleothems as indicators of tectonic movements

In karst caves broken and non-ideal speleothems are very widespread. Mostly they develop because of the instability of the ground due to its composition (loose sand or loam). The presence of recent cryoturbation in some caves in higher altitudes suggests that some ancient breaks of the speleotheme can be caused by ice in the cave. And we also have some good proofs for recent and past tectonic activity in karst caves. In many cases it is very difficult to determine the real reason for broken speleothems, because several reasons could be interacting. In Postojna Cave some examples related to tectonics were studied.
\end{abstract}

Key words: broken speleothems, tectonics, Postojna Cave, Slovenia.

\section{Izvleček}

UDK 552.545:551.248

Stanka Šebela: Pretrta siga kot pokazatelj tektonskih premikov

V kraških jamah pogosto najdemo pretrto in nepravilno sigo. Večinoma nastane zaradi nestabilnosti tal, in sicer zaradi sestave tal (nesprijet pesek in ilovica). Prisotnost današnje krioturbacije $\mathrm{v}$ nekaterih jamah v višjih nadmorskih višinah nas napeljuje na trditev, da je nekatere stare razpoke na sigah lahko povzročila prisotnost ledu v jamah. Imamo pa tudi nekaj dobrih dokazov za današnjo in staro tektonsko aktivnost $\mathrm{v}$ kraških jamah. V večini primerov je težko določiti vzrok za pretrto sigo, ker se med seboj lahko prekriva več vzrokov. V Postojnski jami smo raziskovali nekaj primerov vezanih na tektoniko.

Ključne besede: pretrta siga, tektonika, Postojnska jama, Slovenija.

\section{INTRODUCTION}

In Slovenia but also in other countries the influence of active tectonics in the formation of karst caves is being discussed a lot. After an enthusiastic period when researchers from Slovenia (Gospodarič 1977), Belgium (Quinif \& Genty 1998; Delaby 2001; Vandycke \& Quinif 2001), France (Gilli 1986; Gilli 1992, Gilli 1999a etc.), Italy (Postpischl et al. 1991; Bini et al. 1992) related many broken speleothems with earthquakes or at least with older tectonic events, in recent years some researchers defined ice (Kempe 2004; Gilli 2004) to be one of the principal causes for broken speleothems in the caves.

Becker et al. (2005) determined caves to be a difficult archive, refering to the complexity of the processes. This means that in the study of the cave as a complex en- vironment we cannot select only one cause for broken speleothems, but need to consider more reasons that can interact.

Tectonics in Slovenia is active today, and karst caves are a useful place to search for evidence of deformation. Thin stalactites, stalagmites, flowstone, and helictites may all be easily damaged, and therefore serve as indicators of paleoseismicity. Observations during and after earthquakes, modeling and laboratory experiments indicate that, except for some slender speleothems, cave formations usually do not break during an earthquake.

Most stalactites remain undamaged after an earthquake because their natural frequencies are higher than the maximum for seismic frequencies (which are 0,1

${ }^{1}$ Karst Research Institute ZRC SAZU, Titov trg 2, 6230 Postojna, Slovenia, sebela@zrc-sazu.si

Received/Prejeto: 08.11.2007 
to $30 \mathrm{~Hz}$ ). But, thin and long stalactites may be broken (Lacave et al. 2001).

Regarding ice as a cause for broken speleothems I think we need representative proofs. Delaby (2001) stated that it seems very unlikely that the Hotton cave was affected by frost or permafrost. This is confirmed by the total absence of cryo-clastic features in the surrounding limestone host rock. Frost would probably cause the stalagmite to crumble while the observed breaks are very clean and occur in the lower half of the stalagmite (Delaby 2001). Ice is a kind of cave filling that leaves almost no traces (Becker et al. 2006)
The entrance of Snežna Jama (1556 m above sea level) in Slovenia, is filled with ice and in the cave the effect of the ice on the speleothems is obvious (Gilli 2004). Regarding our experiences the presence and the effect of ice in Postojna Cave described by Kempe (2004) and Gilli (2004) is more doubtful. The ice was probably not so widespread in the cave as is described by Kempe (2004).

With this article I want to show good proofs for broken speleothems related to tectonic deformations. An overview of selected literature will hopefully provoke new prospective studies.

\section{BROKEN SPELEOTHEMS IN KARST CAVES}

The principle causes recognized for speleothem breakage/disruption in karst caves are:

1) Instability of the ground due to its composition (loose sand or clay).

2) Removal of grounding due to water flow

3) Collapse of cave floor (for example into underlying passage).

4) Gravitational deformation close to valleys

5) Ice

6) Changes in drip water resulting in dissolutional loosening of ceiling deposits (for example the falling shield in Škocjanske Jame (Kranjc 1999)).

7) Earthquakes (Bini et al. 1992)

8) Anthropogenic impacts (accidental, mining)

9) Faunal impacts (cave bears, bats etc.)

\section{ABOUT BROKEN FLOWSTONE IN SLOVENE CAVES}

In 1830 , in Postojna Cave, Hohenwart first recognized that fallen stalagmites and stalactites required unusual conditions, and that they might represent geologically important information. He did not, however, determine the specific causes for broken speleothems.

In Postojna Cave it was found that stalactites were broken due to ceiling collapse caused by earthquakes, and also due to the removal of allochthonous sediments (Gospodarič 1968). The same author examined the orientation of broken stalactites and stalagmites in Rov za Veliko Goro passage of Postojna Cave. The passage is filled with flysch sediments and covered by flowstone and collapse blocks. Gospodarič (1968) concluded that some stalagmites fell down from the ceiling together with pieces of the limestone bedrock when aggressive percolation water widened the fissures.

Gospodarič (1968) did not, however, find any good evidence of earthquake damage from the periods of flowstone deposition that were from the Atlantic period (about 6.000-3.000 BC). His directional analysis of the broken stalagmites from Rov za Veliko Goro did not reveal any significant particular direction. He also noted that local ground shaking could be initiated not only through tectonic processes, but also through ceiling collapses or through the development of collapse dolines nearby. However, such local events would not be of sufficient magnitude to break the flowstone (which was 2 metres thick).

In a subsequent study, Gospodarič (1977) investigated a broken speleothem dated at 10.000 BC. In this particular case the speleothem was broken due to consolidation of the underlying loamy sedimentary floor. It was later overturned due to earthquake activity. Compression of loamy sediments is also responsible for consolidation of the cave floor, and consequently the breakage of flowstones in Pisani Rov. This process is a long term one, and therefore cannot be caused by earthquakes.

Gams (2003) mentioned broken stalagmites in Zgornji Tartarus of Postojna Cave. He also described the consolidation of clastic sediments as a cause for broken stalagmites. Perko (1910) believed that a massive stalagmite called Zvrnjeni steber in Postojna Cave (Figure 1) is 150.000 years old, and fell down more than 67.000 years BC. He obtained these age results by calculating and extrapolating from measured deposition rates for flowstone in the cave. On the Zvrnjeni steber some glass plates $(6 \times 3$ $\mathrm{cm}$ ) were installed about 30 years ago. Today some of them are broken and there is also one that is still cemented but curved. It looks as if the crack through the stalagmite is still opening. The movements should be connected with ground instability and not with tectonics. 


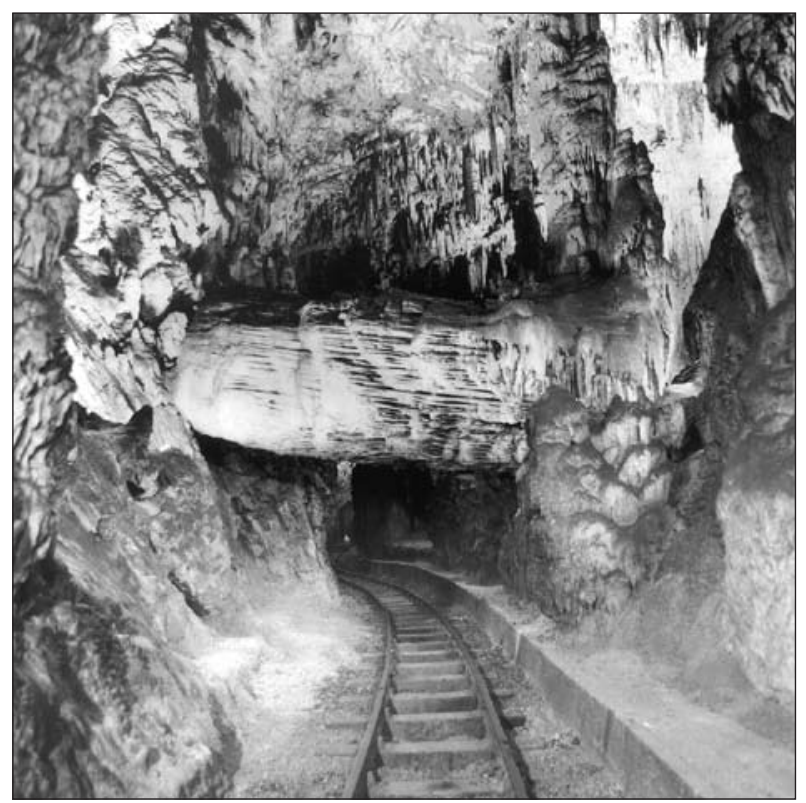

Fig. 1: Zvrnjeni steber in Postojna Cave (photo J. Hajna).

Brodar (1966) thought that frost was the cause of broken flowstone between clastic sediments in the entrance portion of Postojna Cave. Kranjc, in 1999 reports that between March 2 and 3, 1999, a shield style stalactite fell 70 $\mathrm{m}$ from the ceiling of Velika Dvorana in Škocjanske Jame. The weight of the speleothem was estimated at $2.500 \mathrm{ki}-$ los. The speleothem falling was attributable to changes in drip water chemistry. Mihevc (2001) used U-Th dating to determine that breakage of a flowstone deposit in Divaška Jama occurred 176.000 years BC (within the Mindel/Riss interglacial). He did not hypothesize any cause for the breakage. In another cave, Jazbina v Rovnjah, flowstone deformed by cryoturbation was found to be $241 \mathrm{Ka}$ old (Mihevc 2001). In the example of Snežna Jama the flowstone in the entrance area of the cave was broken by frost action. In addition, flowstones deeper in the cave were deformed by cryoturbation (Bosak et al. 2002).

The observations (Gilli 2004) in Postojna Cave and Snežna Jama na Raduhi reveal mechanisms as the creeping of ice or clay filling and in this way explain most of the speleotheme breaks.

The most promising cause for natural speleothem breakage in general in Postojna Cave is, according to Kempe (2004), cave ice. It must have formed in caves during glacial maxima when permafrost spread throughout northern, eastern and central Europe. The ice could be the most prominent factor in explaining non-recent speleothem damage. In the side passages of the cave (Pisani Rov and Brezimenski Rov) there are masses of broken stalagmites and speleothem fragments in precarious positions. Cave ice offers an overall process to explain these observations. It is suggested that all or parts of the Postojna Cave were filled with ice during the last and earlier Glacials (Kempe 2004).

\section{TECTONIC MOVEMENTS DURING THE FORMATION OF KARST CAVES}

Gams (2002) reported on tectonic deformation in three Slovene caves (Postojna Cave, Planinska Jama, Lukenjska Jama), occurring after the passages had been formed. Gospodarič (1964) identified tectonic deformations on the flysch sediments in the artificial passage in Postojna Cave. Maurin (1953) and Wojcik \& Zwolinski (1959) found evidence of Riss/Würm tectonic movements due to shifted cross-sections in caves. In Frassino Cave (Italy), a phreatic passage is offset along a bedding plane reverse fault. Dating of flowstone shows that this movement is older than $350 \mathrm{Ka}$ (Bini et al. 1992).

Through research in Pološka Cave (Figure 2), Habič (1971) found that the passages in one part of the cave are developed close to the crossing of two faults. He indicated that the passages are developed along N-S fault zones. However, he did not mention tectonically offset passages. The fact is that Pološka Cave, which is 10.800 $\mathrm{m}$ long, is located just about $300 \mathrm{~m}$ south from Ravne Fault, which was active in the earthquake of April 12, $1998(\mathrm{Mw}=5.6)$.

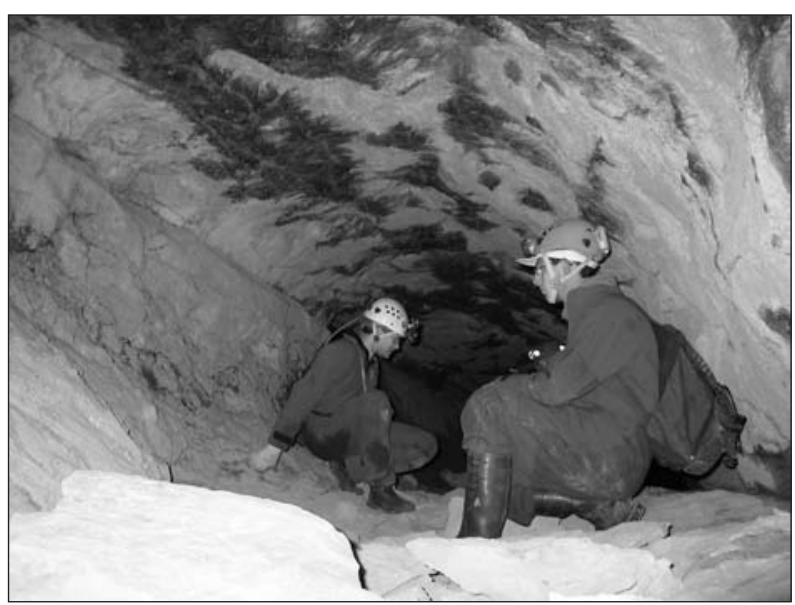

Fig. 2: Pološka Cave, NW Slovenia (photo S. Šebela).

In Kamniška Jama one of the passages ends with a tectonic fault. Urbanc (1982) described that the fault offsets the principal passage into two parts. In connection with that, I have to mention Predjama Cave (Šebela 1996), where the northern wall of the passage at the beginning of Vzhodni Rov has a generally east-west direction, and is basically limited with a fault zone (Figure 3 ). In that example, the cave is developed along the mentioned fault 


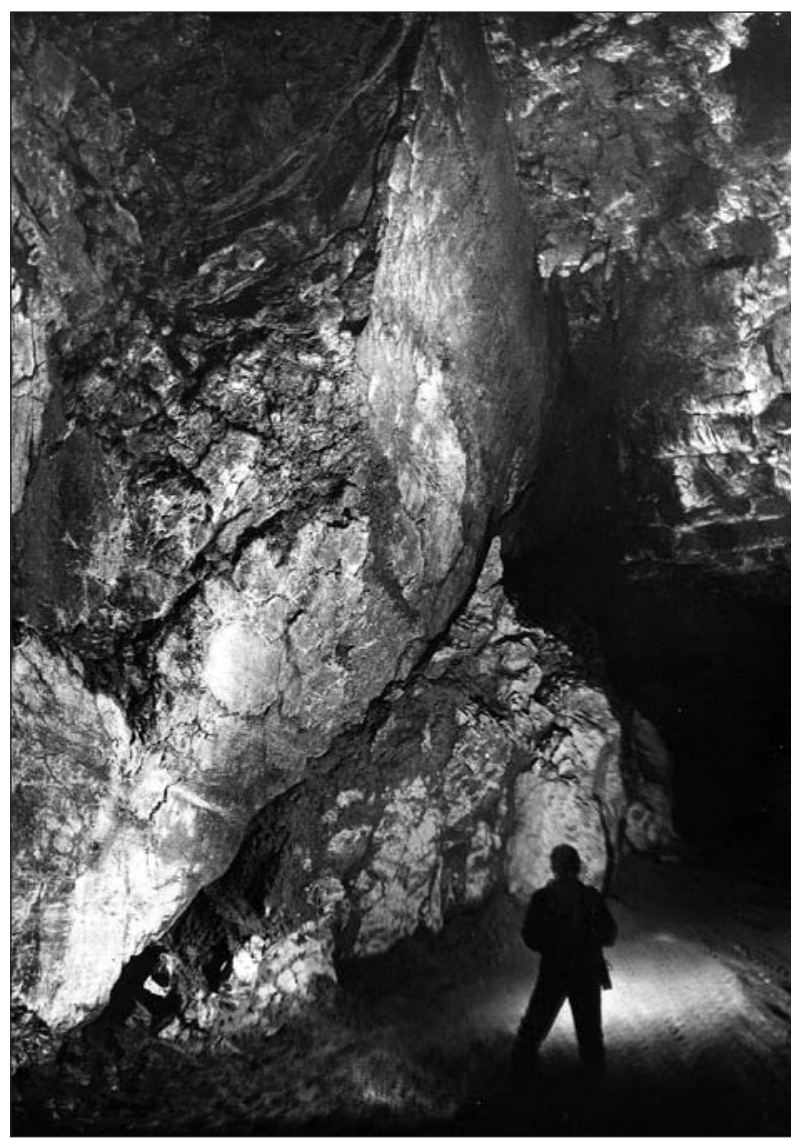

Fig. 3: The fault zone in Vzhodni Rov of Predjama (photo J. Hajna).

zone, which was active before the final formation of the passage.

Čar et al. (2002) described that active tectonics along the northern part of Cerknica Polje is very strong. They compare the position of the systems of Postojna and Planina Caves, with Križna Cave, because between those there is an offset of $12 \mathrm{~km}$, which is due to dextral movement along the Idrija Fault.

During the exploration of the $1,2 \mathrm{~km}$ long and 173 $m$ deep Hirschgrubenhöhle, abundant scratched, sheared and broken speleothems were found. Because Quaternary mass movement and ice-movement in the cave, which are known to cause deformations on speleothems, can be excluded, these deformations are presumably sismothems, i.e. speleothems that were broken or deformed by fault slip associated with seismic events. The cave is located $8 \mathrm{~km}$ south from the master fault of the left-lateral Salzachtal-Ennstal-Mariazell-Puchberg-Line (SEMP). First results suggest that a seismic event with at least 20 $\mathrm{cm}$ offset (sinistral strike-slip) took place between 11-86 $\mathrm{Ka}$ (Plan et al. 2005).

Unstuck parts of the vault, broken stalactites, and horizontally sheared columns show that the Wintimdou- ine Cave in Marocco was and is still modeled during the time of vertical and horizontal shifts that correspond to the contemporary rising up of High Atlas and its thrusting to the south. This dynamic is sprinkled by brief seismo-tectonic events, such as are recorded in speleothems (Angelova et al. 2005).

In the Rochefort Cave (Belgium) the recent tectonic features are bedding planes reactivated as normal faults. The faults are still active because fresh scaling and fallen blocks are observable (Vandycke \& Quinif 2001).

In the shaft of Avent Abel and Calernaum (France), the recent movement of a thrust fault has cause the breakage of many speleothems (Gilli 1992 and 1999 e).

Gilli \& Delange (2001) examined the active movements of thrust faults along which karst caves are developed in France. They found proof of displaced faults and broken flowstone.

\section{EVIDENCES OF SEISMIC EVENTS IN THE CAVES}

Among the older scientists and relation between flowstone and earthquakes, there is a work by Becker (1929) about the Bing Cave in Germany and Han-sur-Lesse (Belgium).

Postpischl et al. (1991) recognized that karst caves have great potential for the study of tectonic, especially paleoseismic, events. They recognized that deviations from vertical growth for stalagmites could be caused by local factors (such as movements of supporting blocks), or they could be due to tectonic events and earthquakes. The evidence for earthquakes in karst caves, can be seen in: deviation of growth axes (from the vertical), differences in flowstone growth, and colour differences in speleothem bands, possibly resulting from changes in the physio-chemistry of percolation water input.

Postpischl et al. (1991) examined the growth of flowstone in two different caves (Buco dei Buio and Spipola near Bologna, Italy), particularly with respect to a strong earthquake that occurred in the region on January 3,1117 . The epicenter was $15 \mathrm{~km}$ far from these caves. They found that the observed anomalies in the stalagmite growths are always related to earthquakes or at least to tectonic events.

In southern Italy, the same researchers (Postpischl et al. 1991) examined Grotta Grande del Cervo. They analyzed 25 stalagmites using $14-\mathrm{C}$ and $\mathrm{U}-\mathrm{Th}$ disequilibrium methods. They were able to connect some morphological deviations in the speleothems with times of known seismic events. The earthquake of December 1456 was particularly obvious. In the last $350 \mathrm{Ka}$ they believe that there were 4 strong earthquakes, with the 1456 one being the most recent. That one, as indicated by archaeo- 
logical studies, closed the entrance to the cave. So, the earthquakes did not only overturn the speleothems, they also caused ceiling collapses and movements of walls. Some stalagmites did not continue to grow afterwards, because the stalactites over them (supplying drip water) had been displaced.

Quinif \& Genty (1998) spoke about the methods by which deformed flowstone can be used for the period of the Holocene and Upper and Middle Pleistocene. And earthquakes from the Holocene can be studied by laminations from the flowstone. In any case it is necessary to do a correlation of the events from different caves. Quinif et al. (1994) also observed that displacements along bedding planes could cause the same stalactite to feed different stalagmites.

Dating of disturbed stalagmites from Grotta Gigante, Italy (Cucchi \& Forti 1989) showed that disruption in growth (reorientation of the growth axis) occurred at 25 $\mathrm{Ka}, 20 \mathrm{Ka}$, and $15-12 \mathrm{Ka}$. They believe that the causes are seismic events.

After the earthquake of February 18, 1996 (magnitude 5.2) in the area of the eastern Pyrenees, France, 8 caves were examined (Gilli 1999 a). They ranged in distance from 2 to $10 \mathrm{~km}$ from the epicenter. The hypocenter was at a depth of 5 to $10 \mathrm{~km}$. On the cave floor they found thin stalactites, which had fallen from the ceiling. One of the caves, Barrenc du Paradet, is located directly on the active fault. The prevalent orientation of the fallen soda-straw stalactites was concordant with the orientation of the fault, and also probably accordant with the direction of maximum ground acceleration of the earthquake. In the same cave some older broken soda-straws, which are evidence of the earthquake of 1922, could be found. These are now covered with newer flowstone deposits. It does not appear that the earthquakes caused the breakage of all soda straws that were present, but rather only those with structural anomalies.

On May 3, 1887 there was a 7.2 magnitude earthquake in Sonora, Mexico. It probably influenced the flowstone about $100 \mathrm{~km}$ away at a cave at Sutherland Peak, Arizona (Gilli 1999 b).

Broken soda straws in the cave in Monaco (Grotte de l'Observatoire) are related to the year 1887, when an earthquake of magnitude 6 to 6.5 occurred. The cave is developed inside a thrust fault on the south and between a vertical fold on the north. The lower layer of the broken flowstone and soda straws in the cave is related to the earthquake from the year 1564 (Gilli 1999 c).

And there is a collapse material within Nimfite Cave, Bulgaria (Angelova et al. 2003), which has been correlated to the 1928 earthquake.

In a study from the south-central massif in France, Camus et al. (2001) made an investigation of flowstone in Garrel Cave, which is cut by a fault that, according to some authors, was active in the upper Pleistocene. They found, however, by analysis of unbroken flowstone in stratigraphic context, that this fault has not been active for $466 \mathrm{Ka}$.

In the Belgian karst (Delaby \& Quinif 2001) they found proof for previously unknown earthquakes. In Hotton Cave they found that $23-55 \%$ of all stalactites are the broken thin stalactites in different parts of the cave. They explained this as caused by an undocumented earthquake with an epicenter somewhere near the cave. Probably the strongest recorded earthquake in eastern Belgium (September 18, 1692) did not leave any breakage evidence in the caves.

There are many broken stalagmites present in the Milandre cave (Swiss Jura), situated about $40 \mathrm{~km}$ far from 1356 Basel earthquake $(\mathrm{Mw}=6.9 \pm 0.5)$. Only most of the long and slender stalactites are expected to break during a "reasonably" strong earthquake, with $0.3 \mathrm{~g}<\mathrm{PGA}$ (peak ground acceleration) $<1 \mathrm{~g}$ (Lacave et al. 2003).

Earthquakes in the Italian Apennines during 1997 in karst caves near Monte Cucco and Frasassi Gorge (about $30 \mathrm{~km}$ from epicenter) caused no large deformations, though perhaps there was some small movement of loose material. However, before the earthquake took place (Menichetti 1998) higher concentrations of $\mathrm{CO}_{2}$ and elevated water temperatures were detected in the caves. Afterwards the highest temperatures and conductivities were measured in nearby springs.

Cavers reported movements from a few centimeters to 5.8 meters in Venetian Alps in Italy. This is supposed to be the displacement of the fossil passage along a vertical fault. They describe a $3.4 \mathrm{~mm}$ displacement and this is according to an experiment with glass plates during 19 years. All of these mentioned displacements are along a single bedding plane, and occurred between 1976 and 1996 (Mocchiutti \& Valent 1998).

In the NE Italian Alps Mocchiutti \& D'Andrea (2002) studied the presence of modern and recent tectonic movements. Caves are the only place where it is possible to recognize with precision the most recent movements on the millimeter scale. Recent observations demonstrate movements with dislocations on the order of a few millimeters to some centimeters. In the cave La Mate (La Bernadia Mt.) the movement observed from 1978-2000 is about $3 \mathrm{~mm}$. In the last years some mechanical measuring instruments (extensometers, fissuremeters and pendulum) have been positioned in same particularly suitable places. The monitoring of one of these extensometers has shown a movement of $0.12 \mathrm{~mm}$ in the period 1999-2002 (Mocchiutti \& D’Andrea 2002).

Speleothems-seismites from the Soreq and Har-Tuv caves located $40 \mathrm{~km}$ due west of the Dead Sea transform 
fault were analysed by U-Th dating and a high resolution $\delta^{18} \mathrm{O}$ profile. Within the $185 \mathrm{Ka}, 38$ seismites were sampled. These stem from 13-18 earthquakes with a mean recurrence interval of 10-14 $\mathrm{Ka}$. The study showed that the deformational events dated in the caves complement independent near-fault paleoseismic records by temporal correlation with the earthquakes recorded therein (Kagan et al. 2005).

Most of the Dead Seas Scrolls, dating from about 200 B.C., were found buried under rubble. Amos Nur contens that earthquakes, including a devastating one recorded in 31 B.C., may have caused the roofs of caves to collapse on top of the scrolls (http://www.stanford.edu/ dept/news/pr/02/scrolls124.html).

\section{REPORTS ABOUT EARTHQUAKES FELT IN KARST CAVES}

The newspaper Edinost ( $8^{\text {th }}$ January 1926) published that during the earthquakes in the area of Postojna between $1-7^{\text {th }}$ January 1926 a big stalagmite ( $1 \mathrm{~m}$ in diameter) in Postojna Cave collapsed (Anon 1926). This was the period of Cerknica earthquakes with the magnitude $\mathrm{Mm}=5.2$ (Ribarič 1982).

Žumer (1996) described the earthquake in Dimnice Cave (Slovenia) on May 22, 1995. There were two earthquakes, of 4 and 4.2 magnitude and an intensity of $\mathrm{V}$ to VI. The epicenter was in the vicinity of the town of Ilirska Bistrica $25 \mathrm{~km}$ away from the cave. The source was $18 \mathrm{~km}$ below the surface. The earthquake did not damage the

\begin{tabular}{|c|c|c|c|}
\hline COUNTRY & CAVE OR KARST AREA & EARTHQUAKE OR SEISMIC EVENT & REFERENCE \\
\hline Belgium & Pere Noel (Han-sur-Lesse) & & Quinif \& Genty 1998 \\
\hline Bulgaria & Douhlata & & Angelova et al. 2005 \\
\hline Bulgaria & Lepenitsa & & Shanov et al. 2001 \\
\hline Bulgaria & Troana cave & $\begin{array}{l}\text { possible coseismic origin in } \\
\text { deformations of speleothems }\end{array}$ & Kostov 2002 \\
\hline Costa Rica & & & Gilli 1997 \\
\hline China & Furong Dong show cave & $\begin{array}{l}\text { during the Febr. } 2003 \text { earthquake } M=3.5 \\
\text { a large number of speleothems were } \\
\text { broken }\end{array}$ & $\begin{array}{l}\text { http://www.hongmeigui. } \\
\text { net/ hmg/news.php?page=4 }\end{array}$ \\
\hline France & La grotte de Villars, Perigord & & Quinif \& Genty 1998 \\
\hline France & $\begin{array}{l}\text { Grotte de Deux Gourdes, } \\
\text { eastern Pirenee }\end{array}$ & $\begin{array}{l}\text { neotectonics and recent movement of } \\
\text { the fault }\end{array}$ & Gilli 1986 \\
\hline France & $\begin{array}{l}\text { Aven de la Portalerie, Causse } \\
\text { du Larzac }\end{array}$ & $\begin{array}{l}\text { detected } 2 \text { earthquakes in the period } \\
36.800-4.500 \text { let BP }\end{array}$ & Bruxelles et al. 1998 \\
\hline Germany & Gaislochhole & $\begin{array}{l}\text { probable coseismic origin of } \\
\text { speleothem breaks }\end{array}$ & Moser \& Geyer 1979 \\
\hline Israel & caves in the Dead sea region & $\begin{array}{l}\text { archaeological records show evidence } \\
\text { of several earthquakes every } 500 \text { y., } \\
\text { including quake of } 31 \text { B.C. }\end{array}$ & $\begin{array}{l}\text { http://www.geotimes.org/feb03/ } \\
\text { feature_stories.html }\end{array}$ \\
\hline Jordan & Khirbet Rufeis cave complex & $\begin{array}{l}\text { damaged by earthquakes in the } 840 \text { s } \\
\text { and } 50 \text { s A.D. }\end{array}$ & $\begin{array}{l}\text { http://www.casa.arizona.edu/ } \\
\text { MPP/rufeis_cave/rufeis.html }\end{array}$ \\
\hline Portugal & Zambujal & prooves for 2 seismic events & Crispim 1999 \\
\hline Romania & $\begin{array}{l}\text { cave system Humpleu, Bihor } \\
\text { Mt. }\end{array}$ & $\begin{array}{l}\text { detected } 2 \text { tectonic events in the last } \\
250.000 \text { years }\end{array}$ & Onac et al. 1998 \\
\hline Switzerland & $\begin{array}{l}\text { area north from the } \\
\text { lakeThoune }\end{array}$ & & Jeannin 1990 \\
\hline Switzerland & Dieboldslochli & Basel earthquake in 1356 with $\mathrm{Mw}=6.9$ & Lemeille et al. 1999 \\
\hline Turkey & Tilkiler & & Gilli 1997 \\
\hline USA & $\begin{array}{l}\text { Coronado cave, Kartchner } \\
\text { caverns and Colossal Cave }\end{array}$ & 1887 earthquake & $\begin{array}{l}\text { http://www.thoughtsandplaces. } \\
\text { org/Caverns/Coronado3.html }\end{array}$ \\
\hline
\end{tabular}

Table 1: Examples of seismic activities in karst environments. 
cave, but the cavers noticed stronger wind flow, sound and splashing water in the underground river.

On the $12^{\text {th }}$ July 2004 the earthquake $(\mathrm{Mw}=5.2)$ with the epicenter $70 \mathrm{~km}$ away was felt in Postojna Cave (Glažar 2006). They did not feel the earth shaking, but the noise as if the train was coming down from Velika Gora towards the Koncertna Dvorana.

While taking the data from TM 71 extensometer in Postojna Cave on January 14, 2005 we heard a noise as if the train was coming and later realized it was an earthquake situated $45 \mathrm{~km}$ NW from Postojna (Cerkno, $\mathrm{ML}=3.8$ ).

In Wind Cave National Park (USA) on March 24, 1964, a tremor caused small rocks to fall in the cave. This was not connected with the great Alaska earthquake (http://neic.gov/neis/states/south/south_dakota/south_ dakota_history.html).

During the very strong Chirpan earthquake in Bulgaria in $1928(\mathrm{Ms}=7.0)$ two men from the village were in the cave and witnessed the breakdowns. The Sherpan cave is about $55 \mathrm{~km}$ to the SW of the epicenter of the earthquake (Kostov 2002).

During the New Madrid earthquakes (1811-1812) rocks cracked in Mammoth cave and large rocks fell in some parts of the cave. On June 10, 1987, an earthquake centre in Laurnenceville, Illinois, with a magnitude of 5.0, caused rocks to fall in Audubon Avenue (http://www. nps.gov/archive/maca/rockfall.pdf).

Cavers report an earthquake (May 1995) with epicenter in the vicinity of Jenolan Caves. In Wiburds Lake Cave they noticed a white rock $1 \times 0.5 \mathrm{~m}$ that must have fallen from the roof, probably during the earthquake (http://www.ee.usyd.edu.au/suss/Bulls/35(2)earthquake. html).

In Table 1 some additional karst caves and karst areas are collected with described earthquake or seismic event.

\section{TECTONICALLY BROKEN FLOWSTONE IN POSTOJNA CAVE}

Experiences of almost 20 years of detailed tectonic-lithological mapping of karst caves in Slovenia (Šebela \& Čar 1991; Šebela 1998) disclosed many examples of the influence of geological structural elements in the formation of karst caves. In most of the cases we have older tectonic deformations, but in some the still active tectonic structures in cave passages can be detected.

In the northern part of Pisani Rov in Postojna Cave the cross-Dinaric oriented (NE-SW) fault cuts through the ceiling (Figure 4). Below the NW end of the fault fresh cracks are visible on the flowstone. Even if the northern end of Pisani Rov is situated just some metres away from the bottom of Velika Jeršanova doline (Šebela \& Čar 2000) we do not believe that the fault is connected

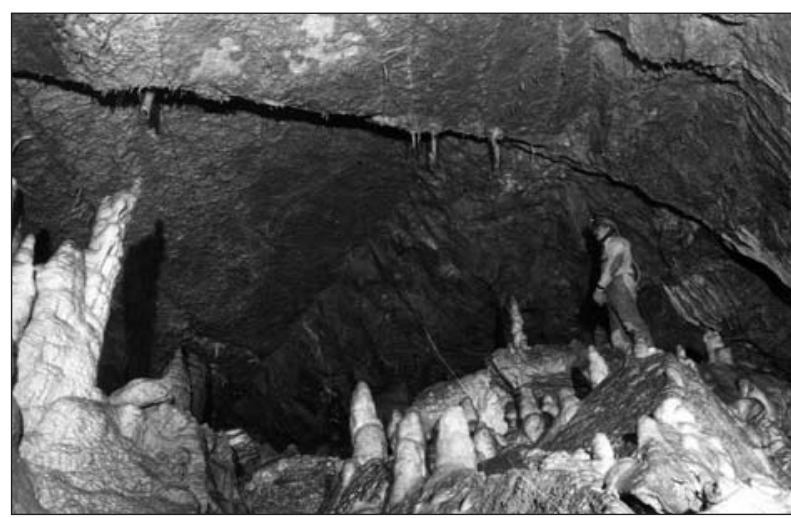

Fig. 4: Cross-Dinaric oriented fault in Pisani Rov of Postojna Cave (photo J. Hajna). with relaxation processes around the doline edge. In such case more joints with fresh cracks would be present, but in our case we have only one fault that looks to be still tectonically active.

One of the best-expressed fault zones in Postojna Cave runs through the collapse chamber of Pisani Rov, continuous on the northern edge of the biggest collapse chamber Velika Gora and narrows in the small side passage of Lepe Jame (Figure 5). Along the Dinaric oriented (NW-SE) fault zone we have the traces of sinistral and dextral horizontal movements, as well as reverse movement in Velika Gora. Regarding results obtained by extensometer TM 71 it looks that the fault zone is still tectonically active with an average $0,02 \mathrm{~mm} /$ year dextral horizontal movement (Gosar et al. 2007). We have the example of slow movement along non-seismogenic fault zone.

Along the same fault zone we can find some broken flowstone that might be the result of tectonic deformations along the fault (Šebela 2005) and not the result of instability of the collapse blocks. The fissure cuts a small flowstone column and it looks as if the lower part of the column has slid, which means the opening of the fault.

Following the same fault zone through the cave passages for a distance about $800 \mathrm{~m}$ one can realize the position of collapse chambers that are developed inside the fault zone. The traces of older tectonic movements are different through out the fault zone. Today's tectonic activity produces micro-deformations, which can be seen as fresh cracks on flowstone. 

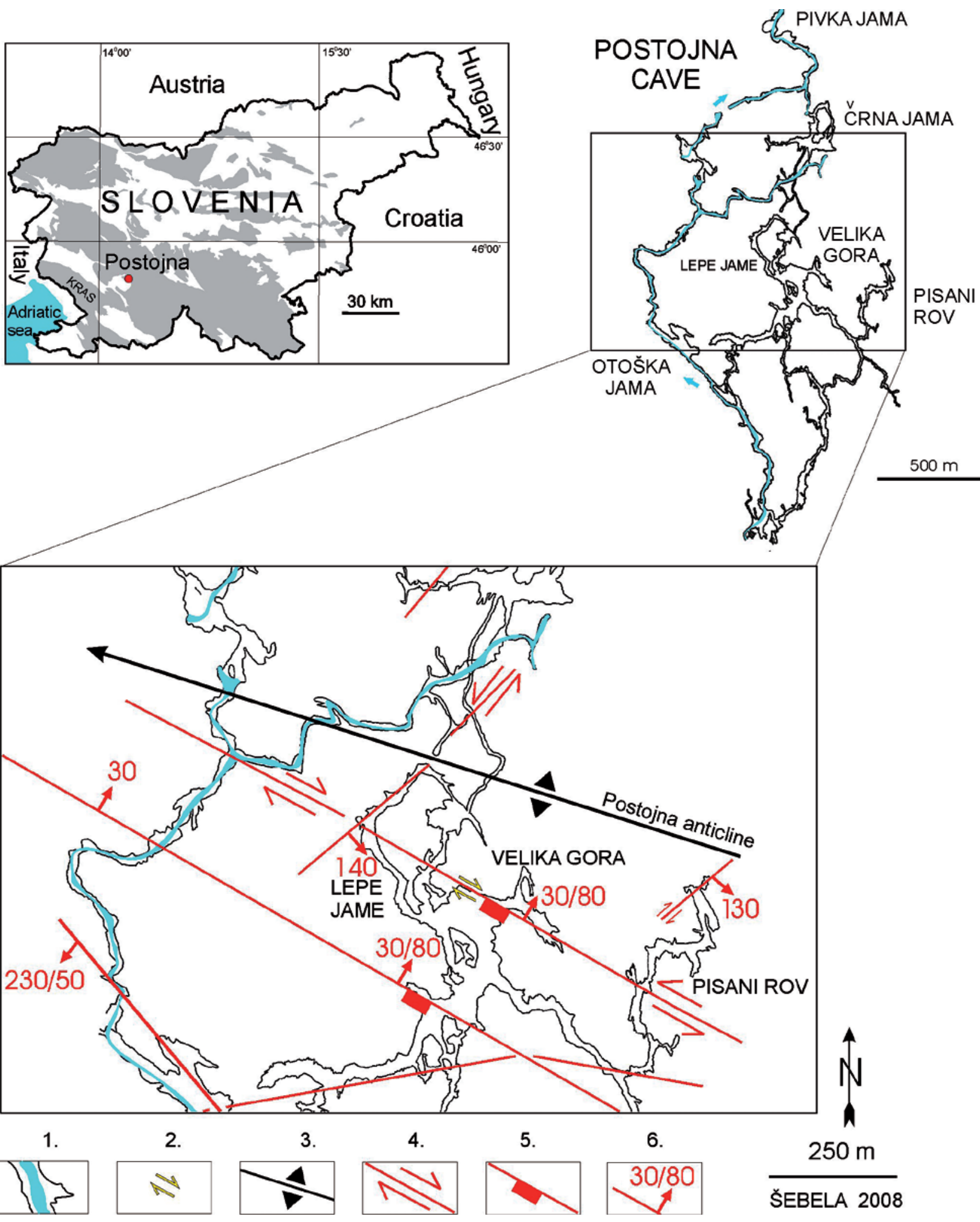

Fig. 5: Collapse chambers in Postojna Cave are aligned along a Dinaric oriented fault zone. 1-underground river, 2-dextral horizontal slow-movement tectonic activity monitored with TM 71 extensometers from the year 2004, 3-Postojna anticline, 4-horizontal movements, 5-vertical movements, 6-strike and dip direction of geological elements. 


\section{CONCLUSIONS}

The traces of neotectonics and active tectonics in Postojna Cave are well documented (Gospodarič 1964; Sasowsky et al. 2003; Šebela 2004). The only description of flowstone column collapse, during the earthquake in Postojna Cave, dates back to the 1926 Cerknica earthquake (Anon 1926). Postojna does not represent a seismically high-risk area but slow tectonic micro-deformations measured with TM 71 extensometers can in 10.000 years of the cave development represent an important factor for speleogenesis. The average $0,02 \mathrm{~mm} /$ year of dextral horizontal movement (Gosar et al. 2007) in 10.000 years, with constant tectonic deformation, represents $2 \mathrm{~m}$ and in 100.000 years $20 \mathrm{~m}$ of the movement. These are not negligible data in the speleogenetic time period.

Earthquakes can be one possible cause for the collapse of speleothems, but mostly it is difficult to prove that flowstone deformation is due to the earthquakes. First, we must eliminate all other possibilities. We have to determine the age of deformation of the flowstone, and statistical analyses of data from a variety of caves (Forti 1997)

Some researchers (Becker et al. 2005; Lacave et al. 2003; Gilli 1999 d) think that to use broken speleothems - preferentially stalagmites - to indicate past strong earthquake shocks is becoming increasingly questionable and is now generally accepted only for the most fragile speleothems, i.e. soda straws.

For cave systems in strong thickly bedded slightly jointed limestones at distance of perhaps $150 \mathrm{~m}$ below the ground surface, damage of walls and roofs are unlikely to take place except in cases of a very large shallow earthquake not far away. During seismic motion most speleothems would not experience dynamic amplifica- tion, but would move with their base as a rigid structure (Becker et al. 2006).

Flowstone being broken due to earthquakes is difficult to verify, because more reasons could be interacting. But from a speleogenetical point of view the effect of slow non-seismogenic movements along fault planes is important. This is the subject of the study in Postojna Cave where the Dinaric-oriented fault is being monitored with TM 71 extensometers from the year 2004 (Gosar et al. 2007).

I believe that the study of past and recent tectonic deformations in karst caves is and will remain one of the important views in speleogenesis. It surely demands other parallel studies that can eliminate or prove other causes for speleothem damage. It is important to detect and date old speleothem damage due to paleotectonic deformations and it is also necessary to find karst caves close to the recent strongly tectonic active areas. I think that detailed studies should be oriented into the karst areas with active tectonics as Indonesia, China, Andes, etc., and should be accompanied by other methods (GPS, Radon and $\mathrm{Hg}$ emanations, 3D extensometer monitoring, precise dating of different tectonic and other events, etc.). In this sense we can compare old speleothem damage due to paleotectonics with recent speleothem breaks due to the earthquakes or slow tectonic non-seismogenic movements. In a natural cave in NE Italy a station for the joint monitoring of horizontal deformation, tilt variations and Radon emanation from the soil operates since 1994 (Garavaglia et al. 1998). Long-term monitoring with various observations is the best answer for understanding the complex karst environment.

\section{ACKNOWLEDGEMENTS}

This study was done with the financial support of the Slovenian Research Agency (programme P6-0119 and project J6-7022), project COST 625 and Slovenia-Czech Republic cooperation in science and technology (projects
BI-CZ/06-07-011 and BI-CZ/08-09-015). I am grateful to Dr. Trevor Shaw and Dr. Ira D. Sasowsky for editing the English text and to dr. P. Forti for constructive review. 


\section{REFERENCES}

Angelova, D., Belfoul, M.A., Bouzid, S., Filahi, M. \& Faik, F., 2003: Paleoseismic phenomena in karst terrains in Bulgaria and Marocco.- Acta carsologica 31/1, 101-120, Ljubljana.

Angelova, D., Belfoul, M.A., Bouzid, S. \& Faik, F., 2005: Karst and cave systems in Bosnek region (Vitosha mountain, Bulgaria) and in Win-Timdouine (High Atlas mountain, Marocco).- Acta Carsologica 34/1, 87-111, Ljubljana.

Anonym, 1926: Iz tržaške pokrajine, Postojna, sedem dni potresa.- Edinost, dne 8.januar 1926, Trst.

Becker, H.K., 1929: Höhle und Erdbeben: Mitt. Über Höhlen-u.Karstf. no. 1-4, p. 130-133.

Becker, A., Ferry, M., Monecke, K., Schnellmann, M. \& Giardini, D., 2005: Multiarchive paleoseismic record of late Pleistocene and Holocene strong earthquakes in Switzerland.- Tectonophysics 400, 153-177.

Becker, A., Davenport, C., Eichenberger, U., Gilli, E., Jeannin, P-Y. \& Lacave, C. 2006: Speleoseismology: A critical perspective.- Journal of Seismology, vol. 10, no. 3, 371-388.

Bini, A., Quinif, Y., Sules, O. \& Uggeri, A., 1992: Les mouvements tectoniques récents dans les grottes du Mont Campo dei Fiori (Lombardie, Italie).- Karstologia 19, 1, 23-30.

Bosak, P., Hercman, H., Mihevc, A. \& Pruner, P., 2002: High-resoultion magnetostratigrapfy of speleothems from Snežna jama, Kamnik-Savinja Alps, Slovenia.- Acta carsologica 31/3, 15-32, Ljubljana.

Brodar, S. 1966: Pleistocenski sedimenti in paleolitska najdišča v Postojnski jami.- Acta carsologica 4, 55139, Ljubljana.

Bruxelles, L., Guendon, J.L. \& Quinif, Y., 1998: Indices de la paléosismicité des grands Causses dans les cavities karstiques: l'exemple de l'aven de la portalerie (larzac, Aveyron).- Speleochronos hors-série, Livre des contributions au colloque "Karst \& Tectonics", Han-sur-Lesse, 9-12 mars 1998, 19-22, Mons.

Camus, H., Seranne, M. \& Quinif, Y., 2001: Activité tectoniques récente enregistrée par les spéléothèmes: un contre exemple sur la faille des Cévennes (sud du Massif Central, Hérault, France).- RIVIERA 2000, Tectonique active et géomorphologie, Villefranchesur-Mer, Revue d'Analyse Spatial-No. Spécial 2001, 53-54, Nice.

Crispim, J. A., 1999: Seismotectonic versus man madeinduced morphological changes in a cave on the Arrábida chain (Portugal).-Geodinamica Acta, vol 12, 3-4, Elsevier, 135-142, Paris.
Cucchi, F. \& Forti, P., 1989: The first absolute datation of a speleothen from Trieste Karst.- Acta carsologica 18, 53-64, Ljubljana.

Čar, J., Šušteršič, F. \& Vrabec, M., 2002: Geomorfologija in aktivna tektonika ob severnem robu Cerkniškega polja.-1.slovenski geološki kongres, Črna na Koroškem, 9-11.oktober 2002, Knjiga povzetkov, 17, Ljubljana.

Delaby, S., 2001: Palaeoseismic investigations in Belgian caves.- Netherlands Journal of Geosciences/Geologie en Mijnbouw 80 (3-4):323-332.

Delaby, S. \& Quinif, Y., 2001: Palaeoseismic investigation in Belgian caves.-Riviera 2000, Tectonique active et géomorphologie, Villefranche-sur-Mer, Revue d’Analyse Spatial-No. Spécial 2001, 67-71, Nice.

Forti, P., 1997: Speleothems and Earthquakes.- 284-285, In: Hill, C. \& Forti, P., Cave Minerals of the World. Second edition, 463 p., NSS, Huntsville.

Gams, I., 2002: O krušenju, premikanju skalnih blokov in tektonskih dislokacijah $\mathrm{v}$ jamah $\mathrm{v}$ Sloveniji.- Naše jame 44, 14-24, Ljubljana.

Gams, I., 2003: Kras v Sloveniji v prostoru in času.Založba ZRC, 516 pp., Ljubljana.

Garavaglia, M., Braitenberg, C. \& Zadro, M., 1998: Radon Monitoring in a Cave of North-Eastern Italy.- Phys. Chem. Earth, vol. 23, no. 9-10, 949-952.

Gilli, E., 1986: Néotectonique dans les massifs karstiques. Un exemple dans les Préalpes de Nice: la Grotte des Deux Gordes.- Karstologia 8, 51-52, Bull F.F.S., Lyon.

Gilli, E. 1992: Au cœur d'un chevauchement dans les gouffres du Calernaum et des Baoudillouns.- Karstologia 19, 39-48.

Gilli, E., 1997: Enregistrement de mouvements recent par l'endokarst.- Archéologie et Sismicité, Édition APDACA, 133-156.

Gilli, E., 1999 a: Research on the February 18, 1996 earthquake in the caves of Saint-Paul-de-Fenouillet area, (eastern Pyrenees, France).- Geodinamica Acta 12, 3-4, 143-158, Paris.

Gilli, E., 1999 b: Evidence of palaeoseismicity in the caves of Arizona and New Mexico (USA).- Surface Geosciences, C.R. Acad. Sci. Sciences de la terre et des planets, 329, 31-37, Paris.

Gilli, E., 1999 c: Breaking of speleothems by creeping of a karstic filling. The example of the Ribière cave (Bouches-du-Rhône).- Surface Geosciences, C.R. Acad. Sci. Sciences de la terre et des planets, 329, 807-813, Paris. 
Gilli, E., 1999 d: Evidence of palaeoseismicity in a flowstone of the Observatoire cave (Monaco).- Geodinamica Acta 12, 3-4, 159-168, Paris.

Gilli, E., 1999 e: Recent, slow and aseismic movement of an overthrust observed in the Abel sink hole (St Vallier de Thiey, 06, France).- Geodinamica Acta 12, 3-4, 169-177, Paris.

Gilli, E., 2004: Glacial causes of damage and difficulties to use speleothems as palaeoseismic indicators.- Geodinamica Acta, 17(3), 229-240.

Gilli, E. \& Delange, P. 2001: Utilisation des spéléothèmes comme indicateurs de néotectonique ou de paléosismicité.- RIVIERA 2000, Tectonique active et géomorphologie, Villefranche-sur-Mer, Revue d’Analyse Spatial-No. Spécial 2001, 79-90, Nice.

Glažar, S., 2006: Strela in potres v Postojnski jami.- Naše jame 46, 118-119, Ljubljana.

Gosar, A., Šebela, S., Košt’ák, B. \& Stemberk, J. 2007: Micro-deformation monitoring of active tectonic stcructures in W Slovenia.- Acta Geodyn. Geomater., vol. 4, no. 1, 87-98.

Gospodarič, R., 1964: Sledovi tektonskih premikov iz ledene dobe v Postojnski jami.- Naše jame 5 (1963), 5-11, Ljubljana.

Gospodarič, R., 1968: Podrti kapniki v Postojnski jami.Naše jame 9 (1-2), 15-31, Ljubljana.

Gospodarič, R., 1977: The collapse of speleothems in the Postojna cave system.- Proceedings of the 7th international speleological congress Sheffield 1977, Hawthornes of Nottingham Limited, 444 p., England.

Habič, P., 1971: Pološka jama-najgloblja v Jugoslaviji.Naše jame 12 (1970), 23-34, Ljubljana.

Hill, C.A. \& Forti, P., 1997: Cave Minerals of the World.National Speleological Society, 463 pp., Huntsville.

Hohenwart, F.J.G., 1830: Wegweiser für die Wanderer in der berühmten Adelsberger- und Kronprinz Ferdinands-Grotte bey Adelsberg in Krain, herausgegeben von Franz Grafen von Hohenwart. Als Erklärung der von Hern Aloys Schaffenrath, k.k. Kreis-Ingenieur in Adelsberg gezeichneten Ansichten dieser Grotte.- I. Helf, 1-16, Wien.

http://neic.gov/neis/states/south/south_dakota/south_ dakota_history.html

http://www.casa.arizona.edu/MPP/rufeis_cave/rufeis. html

http://www.ee.usyd.edu.au/suss/Bulls/35(2)earthquake. html

http://www.geotimes.org/feb03/feature_stories.html http://www.hongmeigui.net/ hmg/news.php?page $=4$ http://www.nps.gov/archive/maca/rockfall.pdf

http://www.stanford.edu/dept/news/pr/02/scrolls 124. html
http://www.thoughtsandplaces.org/Caverns/Coronado3. html

Jeannin, P.-Y.,1990: Neotectonique dans le karst du Nord du Lac de Thoune (Suisse).- Karstologia 15, 41-54, Lyon.

Kagan, E.J., Agnon, A., Bar-Matthews, M. \& Ayalon, A., 2005: Dating large infrequent earthquakes by damaged cave deposits.- Geology, v. 33, no. 4, 261-264.

Kempe, S., 2004: Natural speleothem damage in Postojnska jama (Slovenia), caused by glacial cave ice? A first assessment.- Acta carsologica 33/1, 265-289, Ljubljana.

Kostov, K., 2002: Speleothems as paleoseismic indicators: example from Bulgaria.- Environmental $\mathrm{Ca}$ tastrophes and Recoveries in the Holocene, August 29- September 2, 2002, Department of Geography \& Earth Sciences, Brunel University, UK, selected abstracts.

Kranjc, A., 1999: O odpadanju sige (primer odpadlega stalaktita v Škocjanskih jamah).-Acta Carsologica 28/1, 201-214, Ljubljana.

Lacave, C., Koller, M. \& Levret A., 2001: Measurement of natural frequencies and damping of speleothems.RIVIERA 2000, Tectonique active et géomorphologie, Villefranche-sur-Mer, Revue d'Analyse SpatialNo. Spécial 2001, 99-104, Nice.

Lacave, C., Egozcue, J.J. \& Koller, M.G. 2003: Can broken-and unbroken-speleothems tell us something about seismic history?- 12th European Conference on Earthquake Engineering, paper 349, Elsevier.

Lemeille F., Cushing, M., Carbon, D., Grellet, B., Bitterli, T., Flehoc, C. \& Innocent, C., 1999: Co-seismic ruptures and deformations recorded by speleothems in the epicentral zone of the Basel earthquake.- Geodinamica Acta 12, 3-4, Elsevier, 179-191, Paris.

Quinif, Y., Genty D. \& Maire, R, 1994: Les spéléothèmes: un performant pour les études paléoclimatiques.Bull. Soc. Géol. France, t. 165, no. 6, 603-612, Paris.

Quinif, Y., \& Genty, D., 1998: Sedimentary recording and dating of sismo-tectonic events by the speleothems.Spéléochronos no 9, 27-32, Mons, Belgique.

Maurin, V., 1953: Über jüngste Bewegungen im Grazer Paläozoikum.- Verh. D. Geol. BD., H. 4, Wien.

Menichetti, M., 1998: Central Italy earthquakes of autumn 1997 and the underground karst features of the area.- Speleochronos hors-série, Livre des contributions au colloque "Karst \& Tectonics", Han-surLesse, 9-12 mars 1998, 121 p., Mons.

Mihevc, A., 2001: Speleogeneza Divaškega krasa.Založba ZRC 27, 180 pp., Ljubljana. 
Mocchiutti, A. \& Valent, M., 1998: Evidences morphologiques de mouvements tectoniques récents dans les grottes du Friuli (Nord Est Italie), avec référence particulière aux mouvements postérieurs au tremblement de terre de 1976.- Speleochronos horssérie, Livre des contributions au colloque "Karst \& Tectonics”, Han-sur-Lesse, 9-12 mars 1998, 123-125, Mons.

Mocchiutti, A. \& D’Andrea, A., 2002: Evidenze morfologiche di movimenti tettonici recenti ed attuali, stazioni di monitoraggio in alcune grotte delle Prealpi friulane (Nord-Est Italia).- Mem. Soc. Geol. It., 57, 487-491.

Moser, M. \& Geyer, M., 1979: Seismospeläologie-Erdbebenzerstörungen in Höhlen am Beispiel des Gailoches bei Oberfellendorf (Oberfranken, Bayern).- Die Höhle, v. 30-4, 89-102.

Onac, B.P., Papiu, F., Aanei, M., Bujor, O., Irimie, D. \& Filotie, O., 1998: Neotectonic features in the Humpleu cave system (Bihor Mountains, Romania).- Speleochronos hors-série, Livre des contributions au colloque "Karst \& Tectonics", Han-sur-Lesse, 9-12 mars 1998, 135-136, Mons.

Perko, I.A., 1910: Die Adelsberger Grotte in Wort und Bild.- p. 78, Adelsberg.

Plan, L., Spötl, Ch., Grasemann, B., Decker, K., Offenbecher, K.H. \& Wiesmayr, G., 2005: Seismothems caused by neotectonic activity in the Eastern Alps.14th International Congress of Speleology, 21-28 August 2005, Final Programme \& Abstract Book, 117-118.

Postpischl, D., Agostini, S., Forti, P. \& Quinif, Y., 1991: Palaeoseismicity from karst sediments: the »Grotta del Cervo« cave case study (central Italy).- In: Stucchi, M., Postpischl, D. \& Slejko, D., (Editors), Investigation of Historical Earthquakes in Europe. Tectonophysics, 193 (1991), 33-44, Amsterdam.

Ribarič, V., 1982: Seismicity of Slovenia, Katalog potresov (792-1981).- 649 p., Seizmološki zavod SR Slovenije, Ljubljana.

Sasowsky, I.D., Šebela, S. \& Harbert, W., 2003: Concurent tectonism and aquifer evolution $>100,000$ years recorded in cave sediments, Dinaric karst, Slovenia.Environmental Geology 44, 8-13.
Shanov, S., Kourtev K., Kostov, K., Nikolov, G., Boykova, A. \& Benderev, A., 2001: Palaeoseismological traces in the Lepenitsa Cave, Velingrad district, South Bulgaria.- Tectonique active et géomorphologie, Riviera 2000, Villefranche-sur-Mer 18-22 oct. 2000, Revue d'Analyse Spatial Nº́cial - 2001, 151-154, Nice.

Šebela, S., 1996: The influence of tectonic zones on cross section formations in the Predjama cave, Slovenia.Kras i speleologia, 8 (XVII), 72-76, Uniwersytet Slaski, Katowice.

Šebela, S. 1998: Tectonic structure of Postojnska jama cave system.- Zbirka ZRC 18, 112 p., Ljubljana.

Šebela, S., 2004: Potresi v kraških jamah.- Raziskave s področja geodezije in geofizike, 9.strokovno srečanje Slovenskega združenja za geodezijo in geofiziko, Ljubljana, 15.januar 2004, 5-14, Ljubljana.

Šebela, S., 2005: Monitoring of active tectonic structuresProject COST 625.- Acta carsologica 34/2, 471-488, Ljubljana.

Šebela, S. \& Čar, J., 1991: Geological setting of collapsed chambers in Vzhodni rov in Predjama cave.- Acta carsologica 20, 205-222, Ljubljana.

Šebela, S. \& Čar, J. 2000: Velika Jeršanova doline - a former collapse doline.- Acta carsologica 29/2, 201212, Ljubljana.

Urbanc, J., 1982: Kamniška jama.- Naše jame 23/24 (1981/1982), 25-34, Ljubljana.

Vandycke, S. \& Quinif, Y., 2001: Recent active faults in Belgian Ardenne revealed in Rochefort Karstic network (Namur Province, Belgium).- Netherlands Journal of Geosciences 80 (3-4), 297-304.

Wojcik Z. \& Zwolinski, S., 1959: Mlode przesuniecia tektoniczne w jaskiniach tatrzanskich.- Acta Geol. Pol., vol. IX, Warszawa.

Žumer, J. 1996: Potres v Dimnicah.- Naše jame 38 (1997), 152-154. Ljubljana. 